\title{
Seasonal development and differential retention of ice algae and other organic fractions in first-year Arctic sea ice
}

\author{
Andrew R. Juhl ${ }^{1, *, * *}$, Christopher Krembs ${ }^{2, * *}$, Klaus M. Meiners ${ }^{3,4}$ \\ ${ }^{1}$ Lamont-Doherty Earth Observatory of Columbia University, 61 Route 9W, Palisades, New York 10964, USA \\ ${ }^{2}$ Applied Physics Laboratory, University of Washington, 1013 NE 40th Street, Box 355640, Seattle, Washington 98105-6698, USA \\ ${ }^{3}$ Antarctic Climate and Ecosystems Cooperative Research Centre, Private Bag 80, Hobart, Tasmania 7001, Australia \\ ${ }^{4}$ Australian Antarctic Division, Department of Sustainability, Environment, Water, Population and Communities, \\ 203 Channel Highway, Kingston, Tasmania 7050, Australia
}

ABSTRACT: The temporal evolution of ice algae biomass, particulate and dissolved organic carbon (POC and DOC), and particulate and dissolved carbohydrates (pCHO and dCHO) was followed in land-fast, Arctic sea ice near Barrow, Alaska, USA. POC, DOC, $\mathrm{pCHO}$, and $\mathrm{dCHO}$ were found in young ice before algal growth occurred, indicating initial allochthonous sources. In sediment-free ice, particulate organic pools (POC and $\mathrm{pCHO}$ ) were more strongly related to ice algae biomass than the larger dissolved organic pools (DOC and dCHO). Although algae biomass peaked near the ice bottom, integrating across ice depth showed that most organic matter was found above the bottom layer. Sediment-containing ice held high organic matter concentrations, although peak ice algae biomass was lower than in sediment-free ice. Sediments incorporated in sea ice can be a source of allochthonous organic matter that is comparable to autochthonous contributions by ice algae. In late spring, much of the algae biomass in sediment-free ice was lost, in as little as $5 \mathrm{~d}$. Nevertheless, large POC, DOC, pCHO, and dCHO pools remained in the ice, both near the bottom and in upper layers. Observations of natural ice cores melting in laboratory experiments demonstrated a network of extracellular polymeric substances (EPS) remaining attached to the ice bottom, even as the ice structure melted away. This retained EPS may partly explain the POC and carbohydrate pools found in sea ice after the loss of algae. Differential retention of organic matter by seasonal sea ice suggests that the characteristics of material exported from the ice will change as the melt season progresses.

KEY WORDS: Sea-ice community • Biogeochemistry • Carbon flux - Cryobenthic and cryopelagic coupling • Polar regions · Exopolymer · Chukchi Sea

Resale or republication not permitted without written consent of the publisher

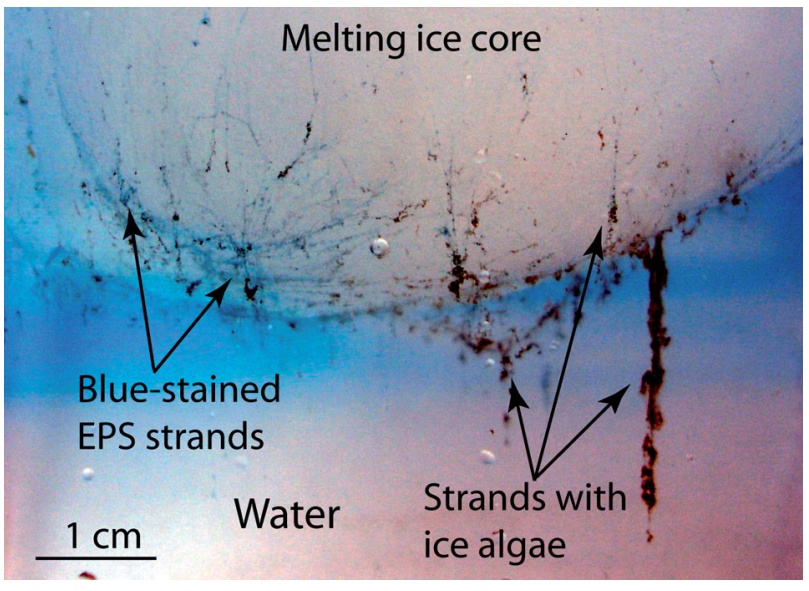

The melting bottom of a sea ice core reveals a network of extracellular polymeric substances to which ice algae are attached.

Image: Andrew R. Juhl

\section{INTRODUCTION}

Because sea ice is porous, brine-filled spaces exist inside the ice that can be colonized by a specialized sympagic community spanning viruses to invertebrates (Horner et al. 1992, Lizotte 2003, Bluhm et al. 2010). Sea ice and its biota play a key role in polar biogeochemistry and ecology (Thomas \& Papadimitriou 2003, Arrigo \& Thomas 2004, Bluhm et al. 2010). Algae growing inside or on the undersurface of the ice (ice algae) contribute significantly to the total annual primary production of polar regions (Legendre et al. 1992, Gosselin et al. 1997, Lizotte 2001, Arrigo \& Thomas 2004). Moreover, primary 
production by ice algae typically peaks in early spring when water-column primary production is negligible. Ice algae, therefore, greatly extend the duration of the productive season in ice-covered seas (Cota et al. 1991, Arrigo 2003, Arrigo \& Thomas 2004).

In first-year Arctic sea ice, most biomass is found in the lower portion of the ice, near or at the ice-water interface. Heterotrophic bacteria dominate the community numerically, but autotrophic diatoms typically dominate biomass during periods when light is available (Lizotte 2003). Following build up of biomass within the ice, algae and other material is lost from the ice to the water column, often in large pulses (e.g. Fortier et al. 2002). Although the mechanisms controlling these fluxes from the ice are not fully understood, such pulses of material export often coincide with increased light, temperature, ice porosity, and/or evidence for ablation of the ice bottom (e.g. Smith et al. 1988, Fortier et al. 2002, Mundy et al. 2005, Juhl \& Krembs 2010). Once exported from the ice, ice algae and other organic materials may be consumed in the water column (Tremblay et al. 1989, Michel et al. 1997), or supply benthic food webs (Ambrose et al. 2001, McMahon et al. 2006, Renaud et al. 2007). Viable algal cells released from the ice habitat may also seed ice-edge blooms (Michel et al. 1993, Haecky et al. 1998). The life cycles of some Arctic marine animals appear to be timed to take advantage of sea-ice productivity and export flux (Bradstreet \& Cross 1982, Runge et al. 1991, Bluhm et al. 2010).

In addition to the living biomass, sea ice holds large reservoirs of non-living organic carbon in both the particulate (POC) and dissolved (DOC) phases. Autochthonous production of organic matter by ice algae and other organisms is clearly an important source, but substantial organic pools may be allochthonously incorporated into sea ice during ice formation (Giannelli et al. 2001, Riedel et al. 2007, Stedmon et al. 2007). Ice algae and other microorganisms can comprise a large fraction of $\mathrm{POC}$, and strong relationships between $\mathrm{POC}$ and chlorophyll have often been described for first-year Arctic sea ice, especially in the ice bottom, where algal biomass tends to peak. Less research attention has focused on POC in the upper ice layers, where biomass is comparatively low. DOC measurements in sea ice are relatively rare compared to POC measurements (Smith et al. 1997, Thomas et al. 2001, Riedel et al. 2008). Smith et al. (1997) and Riedel et al. (2008) found significant positive correlations between sea-ice DOC and chlorophyll concentration in the bottom-most layer of first-year Arctic sea ice, although a clear relationship between organismal abundance and DOC in sea ice is not always apparent (Thomas et al. 2001).

Extracellular polymeric substances (EPS) are components of the non-living organic matter in sea ice that have received much recent research attention because of their potential ecological importance (Meiners et al. 2008, Underwood et al. 2010, Krembs et al. 2011). EPS are secreted in the form of mucous slime or gels by algae and bacteria, and are found in many environments in organic matter ranging from the dissolved, through the colloidal, to the particulate phases (Decho 1990, Wingender et al. 1999, Verdugo et al. 2004). Although EPS are by definition carbohydrate-rich, they also include a complex mix of lipids, nucleic acids, and proteins (Wingender et al. 1999, Underwood et al. 2010). Because quantifying this complex mixture remains difficult, it is common to measure bulk carbohydrates (as we do in the present study), or a component of the carbohydrate pool, as a proxy for total EPS concentration (e.g. Passow \& Alldredge 1995, Krembs et al. 2002, Riedel et al. 2006). For example, in analogy to the transparent exopolymer particles (TEP) found in the water column (e.g. Passow 2002), particulate EPS (pEPS) in sea ice have been detected and quantified by staining with Alcian Blue, which stains acid polysaccharides. Based on Alcian Blue staining, pEPS $(>0.4 \mu \mathrm{m})$ concentrations in sea ice are elevated by an order of magnitude or more over values in the underlying water and contribute from 14 to $78 \%$ of POC in the ice (Krembs \& Engel 2001, Meiners et al. 2004, Riedel et al. 2006). Sea-ice pEPS concentrations are positively correlated with the biomass of ice algae (Krembs \& Engel 2001, Meiners et al. 2003, Riedel et al. 2006), and ice diatoms are a major source of in situ EPS production. Microscopic observations of thin sections of sea ice show ice diatoms and other organisms surrounded by EPS, which may play a role in attachment, locomotion, and cryoprotection (Krembs et al. 2002, 2011, Krembs \& Deming 2007). Most sea-ice-related research to date has focused on pEPS, though some EPS components would be characterized within the dissolved pool. For example, carbohydrates comprise up to $99 \%$ of DOC in Antarctic sea ice (Herborg et al. 2001, Thomas et al. 2001, Underwood et al. 2010). These dissolved carbohydrates may have been released as EPS, or may be derived from EPS breakdown (Underwood et al. 2010).

Although often closely connected, the sources, production, and fate of the various organic matter 
pools in sea ice may be quite different. Understanding the development and loss of the different organic pools found in sea ice provides important insight into the connections between the sea-ice ecosystem and other portions of polar marine food webs. Many previous studies of Arctic sea ice have emphasized the development of organic pools in the ice bottom layer, often the bottom-most few centimeters. In the present study, we compare the temporal development of organic matter pools through the entire ice column in first-year, land-fast Arctic sea ice. The data are organized to document the following observations: (1) POC, DOC, and carbohydrates are found at all depths in young ice, well before significant algal production could occur. (2) Throughout the ice-covered season, substantial POC, DOC, and carbohydrate pools are found at all ice depths, and organic pools in the upper portions of the ice can dominate the total organic content of the ice. (3) The sizes of the organic pools in the upper portions of the ice are less temporally variable than the organic pools near the ice bottom, which can be strongly influenced by autochthonous production. (4) Sediments incorporated in ice may be a significant source of allochthonous organic matter. (5) Dissolved and particulate organic pools have different temporal dynamics, and dissolved organic pools can be substantially larger than particulate pools. (6) The various organic matter pools in sea ice can be differentially retained in the ice as the season progresses. Some of these observations have been described in other studies, and our results both support and expand on earlier observations.

\section{MATERIALS AND METHODS}

All sea-ice sampling locations were within $12 \mathrm{~km}$ of the Barrow Arctic Science Consortium (BASC) field station near Barrow, Alaska $\left(71^{\circ} 20^{\prime} \mathrm{N}, 156^{\circ} 40^{\prime} \mathrm{W}\right)$. Our approach was based on identifying locations of level, homogeneous, first-year, land-fast sea ice through exploratory sampling. Multiple neighboring ice cores were then collected to characterize local conditions, and, when possible, the same location was resampled on subsequent dates to follow temporal changes. On each sampling date, 5 ice cores (or in 2006, 5 pairs of ice cores) were collected. Each core was taken along a linear transect separated from the other cores by 1 to $2 \mathrm{~m}$. When a location was resampled, the transect was shifted by $\sim 0.5$ to $1 \mathrm{~m}$ on successive sampling dates to avoid drilling into previously sampled ice. From year-to-year there were differences in the suite of variables measured within each core, the core diameter, and the number of depth segments analyzed per core. Nevertheless, the similarity in basic sampling and analytical approaches allowed comparison across years, where appropriate. The sampling strategy for different sampling dates is outlined in Table 1, and described in more detail below.

\section{Field sampling winter 2002 to spring 2003}

In December 2002, a location was identified where the ice was visibly free of sediment inclusions. Water depth was $\sim 6 \mathrm{~m}$. This location was sampled on 6 dates between December 2002 and June 2003. On each date, 5 ice cores along a $10 \mathrm{~m}$ transect were collected using a $10 \mathrm{~cm}$ diameter CRREL ice corer driven by an electric drill. The first and second, and the fourth and fifth cores along each sampling transect were processed identically. Immediately after core retrieval, total length was measured and the core was then cut into $10 \mathrm{~cm}$ segments that were sealed in food-grade plastic bags for transport to the laboratory at BASC. Segments proceeded from the bottom up, so that the length of the topmost segment was variable depending on the total length of the ice core. Handling of the third core, in the middle of the transect, differed only in that the vertical temperature profile of that ice core was measured before sectioning, by drilling $3 \mathrm{~mm}$ diameter holes in the side of the ice core every $10 \mathrm{~cm}$ and inserting a digital thermometer probe (accuracy $\pm 0.2^{\circ} \mathrm{C}$ ). During transport to BASC, ice core segments were protected from light and temperature changes in an insulated cooler. In the laboratory, ice cores were gradually melted at $\sim 4^{\circ} \mathrm{C}$ in the dark. After the ice was fully melted, bulk salinity of the meltwater was measured for each segment of each core with a YSI 30 conductivity meter (accuracy $\pm 0.1 \mathrm{ppt}$ ). Subsamples of meltwater from each $10 \mathrm{~cm}$ ice segment of all 5 cores were processed for measuring chlorophyll (chl) $a$ and particulate and dissolved carbohydrates (pCHO and dCHO). In addition, POC, DOC, and inorganic nutrient concentrations were measured on the segments of the third, or middle core, collected on each sampling date. Details of these analyses are described in subsections below. On most sampling dates, 3 water samples were also collected with a bottle sampler that integrated water from 0 to $1.5 \mathrm{~m}$ directly below the ice. Water samples were processed in the same way as the melted ice segments. 
Table 1. Outline of sampling period and analyses conducted for each field season. On all dates between 2002 and 2004,5 cores (10 cm diameter) were collected and divided into $10 \mathrm{~cm}$ segments. In May 2006, core diameter was only $8 \mathrm{~cm}$ so 5 paired cores were collected per date, only the bottom $10 \mathrm{~cm}$ segment of each core was sampled, and matched segments of paired (neighboring) cores were pooled to provide sufficient volume for analyses. Y: yes (analysis was conducted); AC: all cores (analysis was conducted on segments from all ice cores); AS: all segments (analysis was conducted on all $10 \mathrm{~cm}$ segments of the specified cores); N: no (analysis was not conducted); POC: particulate organic carbon; DOC: dissolved organic carbon; pCHO: particulate carbohydrates; dCHO: dissolved carbohydrates

\begin{tabular}{|c|c|c|c|c|c|c|c|}
\hline $\begin{array}{l}\text { Sampling } \\
\text { dates }\end{array}$ & $\begin{array}{l}\text { Temp. } \\
\text { profile }\end{array}$ & $\begin{array}{c}\text { Bulk } \\
\text { salinity }\end{array}$ & Chl a & POC & DOC & $\mathrm{pCHO}$ & $\mathrm{dCHO}$ \\
\hline $\begin{array}{l}3 \text { Dec } 2002-6 \text { Jun } 2003 \\
\text { (6 sampling dates) }\end{array}$ & $\begin{array}{l}1 \text { core } \\
\text { per date }\end{array}$ & $\mathrm{AC}, \mathrm{AS}$ & $\mathrm{AC}, \mathrm{AS}$ & $\begin{array}{c}1 \text { core } \\
\text { per date, AS }\end{array}$ & $\begin{array}{c}1 \text { core } \\
\text { per date, AS }\end{array}$ & $\mathrm{AC}, \mathrm{AS}$ & $\mathrm{AC}, \mathrm{AS}$ \\
\hline 8 Dec 2003 & 1 core & $\mathrm{AC}, \mathrm{AS}$ & $\mathrm{AC}, \mathrm{AS}$ & 1 core, AS & $\mathrm{N}$ & $\mathrm{AC}, \mathrm{AS}$ & $\mathrm{AC}, \mathrm{AS}$ \\
\hline $\begin{array}{c}14 \text { Feb-16 May } 2004 \\
{\text { (4 sampling dates })^{\mathrm{a}}}^{\text {(4) }}\end{array}$ & $\begin{array}{l}1 \text { core } \\
\text { per date }\end{array}$ & $\mathrm{AC}, \mathrm{AS}$ & $\mathrm{AC}, \mathrm{AS}$ & $\begin{array}{c}1 \text { core } \\
\text { per date, AS }\end{array}$ & $\mathrm{N}$ & $\mathrm{AC}, \mathrm{AS}$ & $\mathrm{AC}, \mathrm{AS}$ \\
\hline 8 Dec 2004 & 1 core & $\mathrm{AC}, \mathrm{AS}$ & $\mathrm{AC}, \mathrm{AS}$ & $\mathrm{N}$ & $\mathrm{N}$ & $\mathrm{AC}, \mathrm{AS}$ & $\mathrm{AC}, \mathrm{AS}$ \\
\hline $\begin{array}{l}\text { 12-26 May } 2006 \\
\text { (3 sampling dates) }\end{array}$ & $\mathrm{N}$ & $\mathrm{AC}$ & $\mathrm{AC}$ & $\begin{array}{c}12 \text { and } 26 \\
\text { May only, } \mathrm{AC}\end{array}$ & $\begin{array}{c}12 \text { and } 26 \\
\text { May only, } \mathrm{AC}\end{array}$ & $\begin{array}{c}12 \text { and } 26 \\
\text { May only, } \mathrm{AC}\end{array}$ & $\begin{array}{c}12 \text { and } 26 \\
\text { May only, } A C\end{array}$ \\
\hline
\end{tabular}

\section{Field sampling winter 2003 to spring 2004}

Field procedures were similar to the previous season except that DOC and inorganic nutrients were not analyzed. A location with sediment-free ice was identified and sampled in December 2003, as in the previous year, with the intention of replicating the previous year's time series. However, between December 2003 and February 2004, large-scale ice movements occurred, bringing different ice to the sampling region. The originally sampled ice sheet could not be found, and most of the ice in the area contained visible sediment inclusions. Sampling was therefore restarted in February 2004 in an ice sheet with sediment inclusions. Water depth was $\sim 6 \mathrm{~m}$, as in the previous year. During processing of the icecore segments, the relative sediment concentration accumulated on filters intended for chl a extraction (see 'Analyses of ice samples, chl $a$, and inorganic nutrients') was visually scored on a scale of 0 to 4 , with 0 having no sediment and 4 having the maximum for the core. These scores were used to denote the depth of the sediment layer.

\section{Field sampling December 2004}

A location with sediment-free ice was identified and sampled in December 2004, as in the 2 earlier years. Five cores and 3 water samples were collected as before, but only bulk salinity, chl $a, \mathrm{pCHO}$, and dCHO samples were analyzed.

\section{Field sampling spring 2006}

Observations from earlier years indicated that attention should be focused on late spring during the period when ice algae are lost from the ice. Therefore, in spring 2006 ice coring was conducted on 12, 21, and 27 May in sediment-free ice. Water depth at this location was $\sim 14 \mathrm{~m}$. The ice corer available in 2006 (Kovacs) provided only $8 \mathrm{~cm}$ diameter cores, so to ensure sufficient water volume for different analyses, 5 pairs of neighboring ice cores were collected on each sampling date and pooled together (cores within a pair were separated by only a few centimeters). Logistical limitations restricted us to collecting and analyzing only the bottom $10 \mathrm{~cm}$ segments of these ice cores. Bulk salinity, chl $a$, POC, DOC, $\mathrm{pCHO}$, and $\mathrm{dCHO}$ concentrations were measured in the pooled bottom section from each pair of cores.

\section{Analyses of ice samples, chl $a$, and inorganic nutrients}

Similar procedures were followed from year to year. For chl a concentration, a volumetric subsample 
(20 to $600 \mathrm{ml}$ depending on pigment content) of meltwater from each ice segment was filtered onto a $25 \mathrm{~mm}$ Whatman GF/F filter. Filters were stored frozen $\left(-20^{\circ} \mathrm{C}\right)$ until extraction in $90 \%$ acetone $(24 \mathrm{~h})$ and fluorometric analysis was conducted according to UNESCO (1994) methods.

Inorganic nutrients were analyzed only in samples collected between December 2002 and June 2003. The results of these nutrient analyses were not critical for the conclusions described here and are not discussed further, but the data are available as Tables S1 to S5 in the supplement at www.int-res. com/articles/suppl/m436p001_supp.pdf. Briefly, dissolved inorganic phosphorus and dissolved inorganic nitrogen $\left(\mathrm{NO}_{2}{ }^{-}+\mathrm{NO}_{3}{ }^{-}+\mathrm{NH}_{4}{ }^{+}\right)$were analyzed by the University of Washington Marine Chemistry Laboratory (following UNESCO 1994 methods) in a $16 \mathrm{ml}$ subsample of the filtrate from the chl a sample that was collected and frozen for storage. Analyzing $\mathrm{NH}_{4}{ }^{+}$ on fresh samples on site (i.e. before freezing) was not possible. Nevertheless, given high $\mathrm{NH}_{4}{ }^{+}$concentrations in most samples analyzed, the uncertainty in $\mathrm{NH}_{4}{ }^{+}$values deriving from frozen storage may be small (e.g. Avanzino \& Kennedy 1993).

\section{POC and DOC}

A volumetric subsample $(20$ to $600 \mathrm{ml}$, depending on organic carbon content) of meltwater from each ice segment was filtered onto pre-combusted $\left(450^{\circ} \mathrm{C}\right.$ for $4 \mathrm{~h}$ ) $25 \mathrm{~mm}$ Whatman GF/F filters and frozen for storage. POC on the filters was analyzed by the University of Washington Marine Chemistry Laboratory (following UNESCO 1994 methods) with a Leeman Labs Model CEC440 elemental analyzer. The detection limit was estimated at $0.8 \mu \mathrm{mol} C$ filter $^{-1}$.

Using a custom-built filtration rig, a subsample of the POC filtrate was diverted directly into a sample vial for later DOC analysis. The DOC filtrate was collected after the first 5 to $10 \mathrm{ml}$ of sample had passed through the filter. DOC samples were stored frozen $\left(-20^{\circ} \mathrm{C}\right)$ until analysis by the University of Washington Marine Chemistry Laboratory (following UNESCO 1994 methods). DOC was measured after acidification with $\mathrm{HCl}$ by the high-temperature catalytic oxidation method, with a Shimadzu TOC analyzer with a non-dispersive infrared detector. Detection limit was estimated at $4.2 \mu \mathrm{mol} \mathrm{C}^{-1}$. Acid potassium phthalate was used as the $\mathrm{C}$ standard. The run sequence used by the analytical laboratory consisted of blanks-standards-samples-standards-blanks. Check

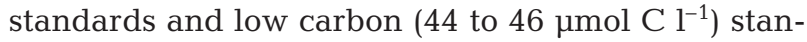

dards provided by Dr. Dennis Hansell's laboratory at the University of Miami are run by the analytical laboratory at regular intervals to ensure performance.

\section{pCHO and dCHO}

To collect material for analyzing pCHO, a volumetric subsample (20 to $600 \mathrm{ml}$ ) of meltwater from each ice segment was gently filtered $(<0.1$ bar vacuum) onto a $25 \mathrm{~mm}, 0.4 \mu \mathrm{m}$ polycarbonate filter (Nuclepore) supported by a pre-combusted GF/F backing filter. In addition, $5 \mathrm{ml}$ of the filtrate was diverted directly into a sample vial for measuring dCHO. Both samples were stored frozen $\left(-20^{\circ} \mathrm{C}\right)$ until later analysis based on the phenol-sulfuric acid method (Dubois et al. 1956). For pCHO, filters were soaked in $5 \%$ phenol and concentrated sulfuric acid in the original sample tubes at $30^{\circ} \mathrm{C}$. The filter was then removed, and the light absorption of the sample at $490 \mathrm{~nm}$ was measured using a Perkin Elmer Lambda2S spectrophotometer with a $1.5 \mathrm{ml}$ polycarbonate cuvette. As separation methods of intracellular and extracellular pCHO are generally very arbitrary, pCHO in the present study included both pools. Water and melted ice samples for $\mathrm{dCHO}$ analysis were first concentrated to a volume of $200 \mu \mathrm{l}$ in a drying oven $\left(80\right.$ to $\left.90^{\circ} \mathrm{C}\right)$. The phenol/sulfuric acid reagent was added (reconstituting the salt concentration to seawater salinity or lower, depending on initial bulk salinity), and the samples were then processed as the pCHO samples. Glucose solutions were used to calibrate $\mathrm{pCHO}$ and $\mathrm{dCHO}$ measurements (the sulfuric acid used in this method breaks carbohydrates down into simple sugars). The carbon content of glucose was used to calculate the carbon content of the carbohydrate fractions.

\section{Observations of melting ice cores}

To observe the process of algal loss from ablating ice, 3 ice cores were collected in 2006 near the sampling location of that year. The bottom $6 \mathrm{~cm}$ of each core was cut off, bagged in plastic, and stored in a cooler for transport back to the field station. Each core segment was suspended with the same orientation as in the field in a transparent acrylic box $(10 \times$ $10 \times 20 \mathrm{~cm}$ ) containing $2^{\circ} \mathrm{C}$ filtered seawater (GF/F). To help visualize EPS, the water used to suspend 2 of the cores was amended with $10 \mathrm{ml}$ of an acid-polysaccharide-staining Alcian Blue solution (Passow \& Alldredge 1995), which slowly dispersed below the 
ice. The 3 suspended cores were placed in a $2^{\circ} \mathrm{C}$ incubator and photographed periodically (using a Sony DSCP 200 digital camera) over the subsequent $24 \mathrm{~h}$.

\section{RESULTS AND DISCUSSION}

\section{Young, sediment-free ice in December}

Young, first-year, fast ice was sampled in early December 2002, 2003, and 2004. These samples all had little to no visible sediment inclusions (described as 'sediment-free'). Organic pools are summarized in Fig. $1 \mathrm{~A}$ to $\mathrm{C}$ (detailed data available in Tables S1 to S5). Profiles of $\mathrm{POC}, \mathrm{pCHO}$, and dCHO were relatively uniform with depth. For example, mean values of $\mathrm{pCHO}$ and $\mathrm{dCHO}$ from the upper and bottom $10 \mathrm{~cm}$ segments in each year were not significantly different from each other (t-tests, $p>0.08$ in each case). This contrasts with data from later in the season when dramatic differences between the upper and lower ice layers developed for many variables in sediment-free ice (see next subsection). POC was measured in a single ice core (in December 2002 and 2003 only) and therefore could not be tested statistically in this fashion. However, in those years, POC at each depth varied from the overall mean by $<25 \%$. DOC was only analyzed in December 2002, and the DOC profile from that year's samples contrasted with the other variables in showing a top to bottom increase by a factor of 2 . In each year when the com- parison could be made, the following generalizations were true across all depths: pCHO was less than POC, dCHO was less than DOC, POC was less than DOC, and pCHO was less than dCHO. Thus, dissolved organic pools always exceeded the particulate pools.

The ice may not have formed from the underlying water sampled when the cores were collected, nevertheless, comparing water and ice provides valuable context. Mean POC in the underlying water overlapped with the range of POC found in the ice in both years when it was measured. Similarly, pCHO values in the ice and water also overlapped each year, although pCHO in the water was slightly lower than most values in the ice. By contrast, DOC and dCHO in the water generally exceeded values in the ice. In 2002, mean dCHO in the water exceeded mean ice dCHO by at least a factor of 2. In 2003 and 2004 the difference between water and ice was smaller; mean water dCHO was elevated by, at most, $40 \%$ over the highest mean value in the ice. Thus, comparing ice with water, particulate organic pools in the ice were greater than or equal to values in the water, while dissolved pools in the water generally exceeded values in the ice. As was found in the ice, water DOC exceeded POC (only measured in December 2002), and $\mathrm{dCHO}$ in the water always exceeded $\mathrm{pCHO}$ (all years).

Due to low light availability in winter, it is likely that ice POC, DOC, and CHO in early December were primarily allochthonous. Allochthonous enrichment in sea ice was described in Riedel et al. (2007),
A) $\operatorname{Dec} 3,2002$

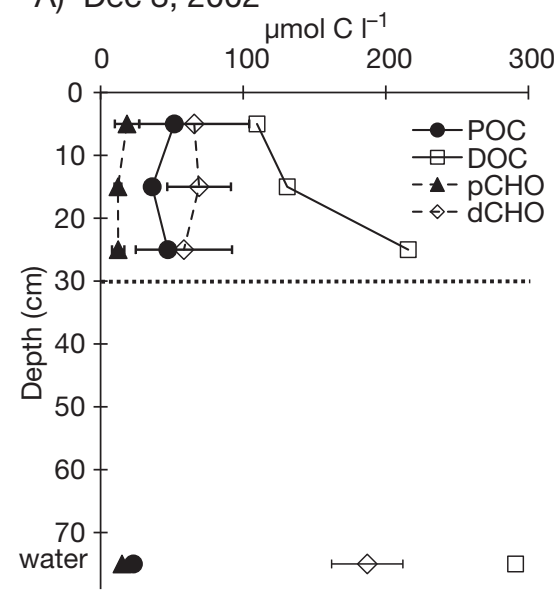

B) $\operatorname{Dec} 8,2003$

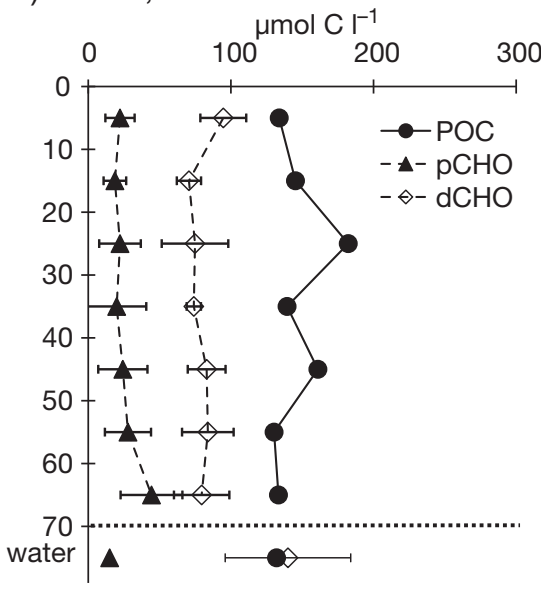

C) Dec 8, 2004

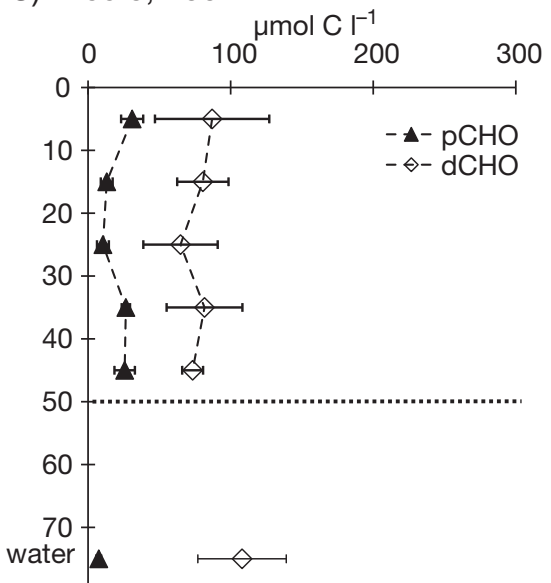

Fig. 1. Depth profiles of organic matter within sea ice in early December of (A) 2002, (B) 2003, and (C) 2004. Water data also shown at the bottom of each plot. Bulk particulate carbohydrates (pCHO) and dissolved carbohydrates (dCHO) were measured in all years, and the symbols represent mean values ( $\pm 1 \mathrm{SD}$ ) of $10 \mathrm{~cm}$ ice segments at a given depth from 5 replicate ice cores. Bulk particulate organic carbon (POC) and dissolved organic carbon (DOC) were only analyzed in 1 of the 5 cores. Points are plotted for the mid-depth of the segment. POC was not analyzed in 2004, and DOC was not analyzed in 2003 or 2004 
who found chl $a$, pEPS (which would be measured as a component of the pCHO pool in the present study), bacteria, and protists to be enriched relative to the underlying water in coastal Arctic sea ice that was hours to days old. Similarly, in 5 d old, experimentally produced sea ice, Giannelli et al. (2001) found DOC enrichment relative to expectations based on concentrations of DOC in the water. In contrast, Stedmon et al. (2007) found low DOC in Baltic sea ice compared to the water. Although the ice sampled in Stedmon et al. (2007) was several months old (collected in midMarch), they nevertheless concluded that the DOC was primarily allochthonous. Our December findings are more similar to those of Stedmon et al. (2007) in that we did not find evidence of significant allochthonous enrichment of ice organic pools relative to the underlying water either. The difference in organic enrichment of sea ice between studies could reflect ice age, in that newly formed natural sea ice (as in Riedel et al. 2007) is typically dominated by frazil ice, while older ice (such as that we sampled, even in December) tends to be dominated (volumetrically) by congelation ice (Eicken 2003). It is possible that these 2 types of ice differ in how materials are scavenged or incorporated from the water. Breakdown or loss of allochthonously incorporated material could play a role, but the low temporal variability of the upper ice organic pools in our subsequent sampling is not consistent with that possibility (see next section).

\section{Organic pools in sediment-free ice}

Following the December 2002 sampling described above, the same location continued to be periodically sampled until early June 2003, allowing the development of organic pools in the ice sheet to be followed through most of the spring. Fig. 2A to $\mathrm{H}$ shows summary data; detailed data are given in Table S1 in the supplement. In each plot, the data were pooled into mean values for 4 depth strata within the ice to help visualize general trends for the upper, upper middle, lower middle, and bottom layers of the ice. Fig. 2A shows the mean depths for each of the 4 layers through time. Results shown for the bottom layer were always from the bottom $10 \mathrm{~cm}$ section of the ice. The 3 upper layers were progressively defined as the ice thickened, each layer consisting of at least two $10 \mathrm{~cm}$ ice segments. Thus, in December 2002, when the ice was $30 \mathrm{~cm}$ thick, there was only a bottom and an upper layer (the upper $20 \mathrm{~cm}$ of the ice). The additional middle layers were added as the ice thickened.
Mean depths of the upper 3 layers changed little through time after they were progressively established, although the depth of the bottom layer increased as the ice thickened through time (Fig. 2A). Temperature (Fig. 2B) initially decreased with depth in the ice. However, by early May 2003, the ice was nearly isothermal, and, by June, the upper ice was slightly warmer than the lower layers. Bulk salinity was initially highest in the upper layer (Fig. 2C). A declining trend in the upper layer beginning in March 2003 was initially accompanied by an increase in bulk salinity of the bottom and middle layers. This suggests gradual brine drainage within the ice. Indeed, by June 2003, the bottom layer had the highest bulk salinity.

Chl a increased in the ice bottom layer from early February through early May, then decreased by early June (Fig. 2D). After the December sampling, the highest chl a concentration was always found in the bottom layer. From that point forward, chl a concentrations in the upper and bottom layers were significantly different (t-tests with Welch's correction, $\mathrm{p}<0.004$, on each date) until the last sampling in June $\left(t_{4}=2.563, \mathrm{p}=0.06\right)$. Similar to the chl a pattern, POC in the ice accumulated primarily in the bottom layer (Fig. 2E). Because POC was only measured on a single core, the difference between the upper and bottom layers could not be tested statistically, but from 6 April onward, POC in the bottom layer exceeded the concentration in the upper layer by at least a factor of 4 . Unlike the chl a observations, POC in the bottom layer did not decrease by the June sampling. An increase in pCHO was also observed through time in the bottom layer (Fig. 2F), but the difference between the upper and bottom layers was not significant until the last sampling date ( $t$-test with Welch's correction, $\left.t_{4}=4.131, \mathrm{p}=0.015\right)$, after the chl a concentration had decreased.

For particulate materials (chl a, POC, pCHO), dates when the concentrations in the bottom layer differentiated from those in the upper layer also marked large differences between the ice bottom and the underlying water. Mean chl a concentration in the water ranged from 0.04 to $4.0 \mu \mathrm{g} \mathrm{l}^{-1}$, generally increasing with time. After the December sampling, mean chl $a$ in the ice bottom layer exceeded that in the water by a factor of 2.5 to 179 . These differences were significant on each sampling date ( $t$-tests with Welch's correction, $\mathrm{p}<0.003$ on each date), except for the final sample in June after chl $a$ in the ice had decreased. POC in the water ranged from 11 to

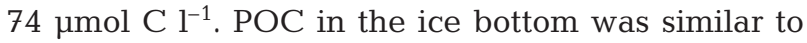
that in the water before 6 April, but exceeded POC in 

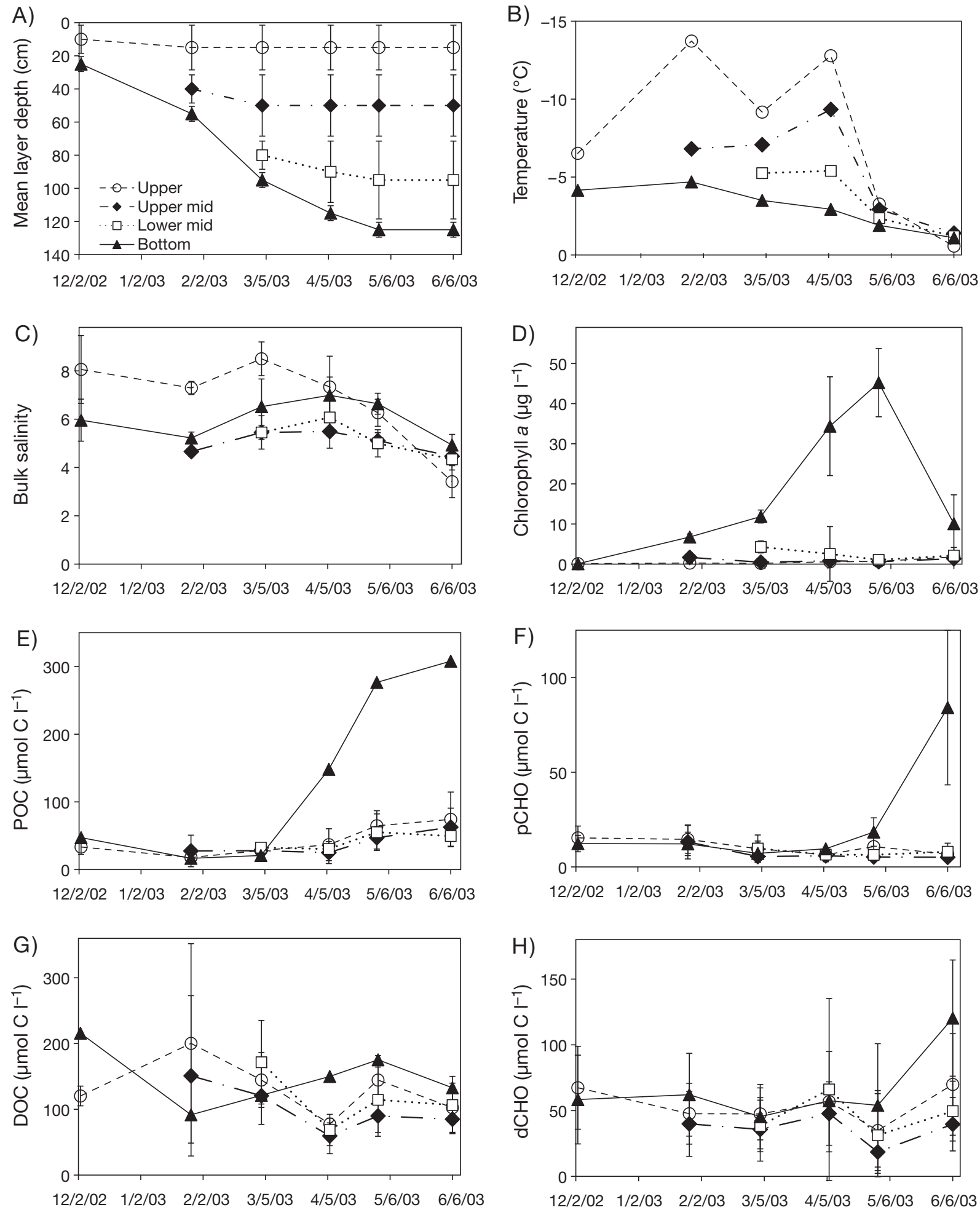

Fig. 2. Temporal development of physical, chemical, and biological variables in sediment-free sea ice sampled from winter 2002 to spring 2003. Each panel (A to H) shows the mean of a single variable through time for 4 layers defined by depth within the ice: upper, upper middle, lower middle, and bottom layers. (A) Depth (bars show the depth range of ice sections pooled into each layer), (B) temperature (note reversed $y$-axis), (C) bulk salinity, (D) bulk chl $a$, (E) bulk particulate organic carbon (POC), (F) bulk particulate carbohydrates (pCHO), (G) bulk dissolved organic carbon (DOC), and (H) bulk dissolved carbohydrates (dCHO) are shown. For bulk salinity, chl $a, \mathrm{pCHO}$ and $\mathrm{dCHO}$, samples from 5 replicate ice cores were analyzed on each date. For the bottom layer (bottom $10 \mathrm{~cm}$ ), the symbol is the mean $( \pm 1 \mathrm{SD})$ of the bottom layer across the 5 cores. For each of the 3 upper layers, the symbol is the grand mean ( \pm the pooled SD) of all segments within a depth layer from all cores collected on each date. POC and DOC were only analyzed for 1 of the 5 cores from each date. Thus, for the bottom layer, each symbol represents the value from the bottom $10 \mathrm{~cm}$ of a single ice core. For the upper layers, each symbol is the mean ( $\pm 1 \mathrm{SD})$ of all segments within each layer from a single core. Dates: month/day/year 
the water by 4 - to 13 -fold from then on. Concentrations of pCHO in the water ranged from 4 to $21 \mu \mathrm{mol}$ $\mathrm{Cl}^{-1}$. Mean values in the ice bottom layer and water were similar until the June sampling when the concentration in the ice exceeded that in the water by a factor of 4 . This was the only date when $\mathrm{pCHO}$ in the ice significantly exceeded the amount in the water $\left(t_{6}=2.6, \mathrm{p}=0.04\right)$. See Table S1 in the supplement for detailed data on concentrations of particulates in the underlying water.

In contrast with the particulate substances measured in the ice, differences between the upper and lower ice layers, or between the lower ice and the underlying water, were relatively small for the dissolved organic substances measured. DOC in the ice did not change consistently with time in any layer (Fig. 2G), and differences between the bottom and upper layers were always a factor of 2 or less. DOC in the water ranged from 114 to $291 \mu \mathrm{mol} \mathrm{C} \mathrm{l}{ }^{-1}$, overlapping the range in the ice bottom. On each sampling date, the values in the ice bottom layer and water were within a factor of 2. Similarly, dCHO values in the upper and bottom layers were also always within a factor of 2 of each other (Fig. 2H), and, although $\mathrm{dCHO}$ peaked in the ice bottom in June, the difference between the bottom and upper layers was not significant on any date ( $t$-tests, $\mathrm{p}>0.09$ on each date). In the water, dCHO ranged from 127 to $253 \mu \mathrm{mol} \mathrm{Cl}^{-1}$, and always exceeded the value in the ice bottom. However, the difference between the water and the ice bottom was only significant on the first 2 sampling dates ( $t$-tests, $\mathrm{p}<0.005$ on the first 2 dates, $\mathrm{p}>0.09$ on other dates).

Although concentrations of many organic constituents (especially particulates) were relatively low in the upper ice layers, because of their relative thickness, the upper layers of the ice nevertheless contained large organic reservoirs (Fig. 3). As the ice algal bloom developed in the bottom layer, the percent of integrated chl a found in the upper layers progressively declined through April to a minimum of $18 \%$. After the decline of the algal bloom in the bottom layer, the percent of integrated chl a found in the upper layers increased to $68 \%$. By contrast, the majority of integrated POC and DOC was always found in the upper layers. However, in relation to temporal variability in the bottom layer, the magnitude of the organic pools found in the upper ice layers changed little through time. One possibility is that allochthonous material incorporated into the ice early in the ice-covered season (see preceding section) persisted relatively unchanged. Thus, despite their magnitude, the upper ice layers played a com- paratively small role in net changes in the size of organic pools in the ice through time, other than increases related to ice thickness. Nevertheless, the upper organic pools should not be thought of as passive reservoirs. Active, or at least potentially active, prokaryotic and eukaryotic communities are found in all parts of Arctic sea ice (Gradinger et al. 1991, Hsiao 1992, Junge et al. 2004, Eddie et al. 2010). Given the difference in temporal dynamics, the composition and lability of organic matter in the upper and bottom ice layers are likely different, and the comparison deserves more detailed study.

The Pearson correlation coefficients and corresponding p-values for pairs of variables measured in the 2002 and 2003 samples are given in Table 2. Of note were the highly significant correlations between POC and chl $a, \mathrm{pCHO}$, and dCHO. In addition, $\mathrm{pCHO}$ and $\mathrm{dCHO}$ were significantly correlated; however, POC and DOC were not. Although chl a was positively correlated with $\mathrm{POC}$, it was not correlated with DOC, pCHO, or dCHO. However, considering only the period when chl a was increasing (by excluding data from the last sample date), chl a was significantly correlated with other particulates (with POC: $\mathrm{r}=0.82, \mathrm{p}<0.0001, \mathrm{n}=43$; with pCHO: $\mathrm{r}=0.3$, $\mathrm{p}=0.04, \mathrm{n}=43$ ), though still not with DOC or dCHO. If the analysis was restricted to the bottom layer only, chl a was not significantly correlated with any of the bulk organic pools: $\mathrm{POC}, \mathrm{DOC}, \mathrm{pCHO}$, or $\mathrm{dCHO}(\mathrm{n}=$ $6, \mathrm{p}>0.26$ in each case). Excluding the last sampling date resulted in a positive correlation between chl $a$ and POC in the bottom layer $(\mathrm{r}=0.93, \mathrm{p}=0.02, \mathrm{n}=5)$, but not with other organic pools ( $p>0.24$ for $p C H O$, DOC, and dCHO).

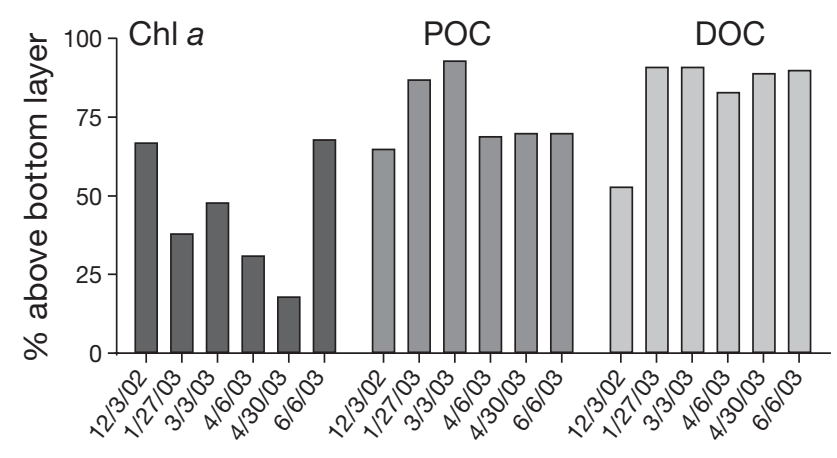

Fig. 3. Percent of total depth-integrated organic matter found in the upper layers of sediment-free sea ice sampled from December 2002 to June 2003. The upper layers are any part of the ice above the bottom $10 \mathrm{~cm}$ segment. Data are shown for 3 pools (as labeled): chl a (representing algal biomass), particulate organic carbon (POC), and dissolved organic carbon (DOC). Dates: month/day/year 
Table 2. Correlation matrix for the primary variables sampled in sediment-free ice from winter 2002 to spring 2003. Correlations were based on the mean values for each variable at a given depth from 5 ice cores (except particulate organic carbon $[\mathrm{POC}]$ and dissolved organic carbon [DOC], which were measured in single ice cores on each date). Different depths and times were considered independent, resulting in 57 data pairs for each correlation. For each data pair, the Pearson correlation coefficient (r) and, in parentheses, the corresponding $\mathrm{p}$-value are given. Bold: correlations with $\mathrm{p}<0.05$. pCHO: particulate carbohydrates; dCHO: dissolved carbohydrates

\begin{tabular}{|c|c|c|c|c|c|c|}
\hline & Bulk salinity & Chl a & POC & DOC & $\mathrm{pCHO}$ & $\mathrm{dCHO}$ \\
\hline Temperature & $0.65(<0.0001)$ & $0.22(0.09)$ & $0.38(0.0027)$ & $0.17(0.21)$ & $0.06(0.67)$ & $0.07(0.58)$ \\
\hline Bulk salinity & - & $0.10(0.45)$ & $0.08(0.56)$ & $0.29(0.02)$ & $0.09(0.52)$ & $0.05(0.70)$ \\
\hline Chl a & & - & $0.66(<0.0001)$ & $0.17(0.21)$ & $0.23(0.07)$ & $0.16(0.23)$ \\
\hline POC & & & - & $0.16(0.22)$ & $0.68(<0.0001)$ & $0.34(0.008)$ \\
\hline DOC & & & & - & $0.20(0.13)$ & $0.02(0.88)$ \\
\hline $\mathrm{pCHO}$ & & & & & - & $0.51(<0.0001)$ \\
\hline
\end{tabular}

In general, the particulate organic pools increased through time, accumulated especially in the ice bottom, and correlated positively with chl a (at least, while chl a was increasing), all indicating autochthonous production related to ice algae. The dissolved organic pools were less dynamic and showed little connection to algae. This result contrasts with other studies that have found a correlation between DOC and ice algae or other organic pools in the bottom layer of Arctic sea ice (Smith et al. 1997, Riedel et al. 2008). However, those studies sampled ice that supported much denser algal blooms, with peak chl a concentrations at least an order of magnitude higher than in the samples presented here. In other sampling of fast ice near Barrow, we have also encountered bottom-ice chl a concentrations of at least 10 -fold the maximum values reported here, with correspondingly higher DOC concentrations (C. Krembs \& A. R. Juhl unpubl. data). Thus, although ice algae can be a source of DOC in Arctic sea ice, the autochthonous DOC signal may be difficult to detect against the background signal of allochthonous DOC, unless the algal biomass is high.

\section{Organic pools in sediment-containing ice}

A location with sediment-containing ice was sampled from February through May 2004. The data are summarized in Fig. 4A to $\mathrm{H}$ in a similar format as that in Fig. 2 (for detailed data see Table S4). Fig. 4A shows the mean depths of the upper, upper middle, lower middle, and bottom layers of the ice, which changed little through time except for the increasing depth of the bottom layer. Fig. 4B shows the gradual increase in temperature of the upper layers through time. Temporal changes in bulk salinity (Fig. 4C) were relatively small compared to the observations from sediment-free ice, suggesting weaker brine drainage compared to the ice sampled the previous year. Sediment was found primarily in the upper and upper middle layers (Fig. 4D). Ice with internal sediment inclusions is common near shore in the Beaufort and Chukchi Seas and is frequently encountered in the land-fast ice near Barrow (Gradinger et al. 2009, Lee et al. 2010), probably due to suspension freezing during early phases of ice formation (Reimnitz et al. 1992). Little sediment was found in the deeper, younger layers of ice, until the last sampling date, by which time ice temperature had become nearly isothermal with depth. It is possible that some sediment, originally restricted to the upper ice, could have moved vertically as porosity increased with temperature. Chl a concentrations in the sediment-containing ice were consistently lower than in the sediment-free ice from 2003 (Fig. 4E). Nevertheless, by the last sampling date, a chl a peak had formed in the bottom layer that was significantly different from that in both the upper layer ( $t$-test with Welch's correction, $t_{4}=$ 4.05, $\mathrm{p}=0.02$ ) and the underlying water ( $t$-test with Welch's correction, $t_{4}=4.85, \mathrm{p}=0.008$ ). Despite the increase in chl $a$ in the ice bottom by the last sampling date, concentrations of $\mathrm{POC}$ and $\mathrm{pCHO}$ in the bottom layer were similar to concentrations in the upper layers (Fig. 4F, G; $t$-test on pCHO concentrations, $t_{8}=1.3, \mathrm{p}=0.24$ ). This may be because POC and $\mathrm{pCHO}$ concentrations were high (at least relative to the sediment-free ice sampled in the previous year), especially in the sediment-containing upper layers. The range of POC (74 to $402 \mu \mathrm{mol} \mathrm{C} \mathrm{l}^{-1}$ ) and

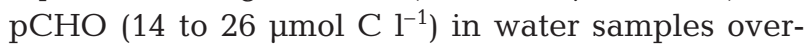
lapped with those from the previous year, but were generally higher. However, even peak values in the water were still lower than peak values in the upper ice layers. This suggests that $\mathrm{POC}$ and $\mathrm{pCHO}$ values in the water would not explain the high values in the ice, especially for the upper ice layers. Mean dCHO values were nearly identical in all layers of the ice 

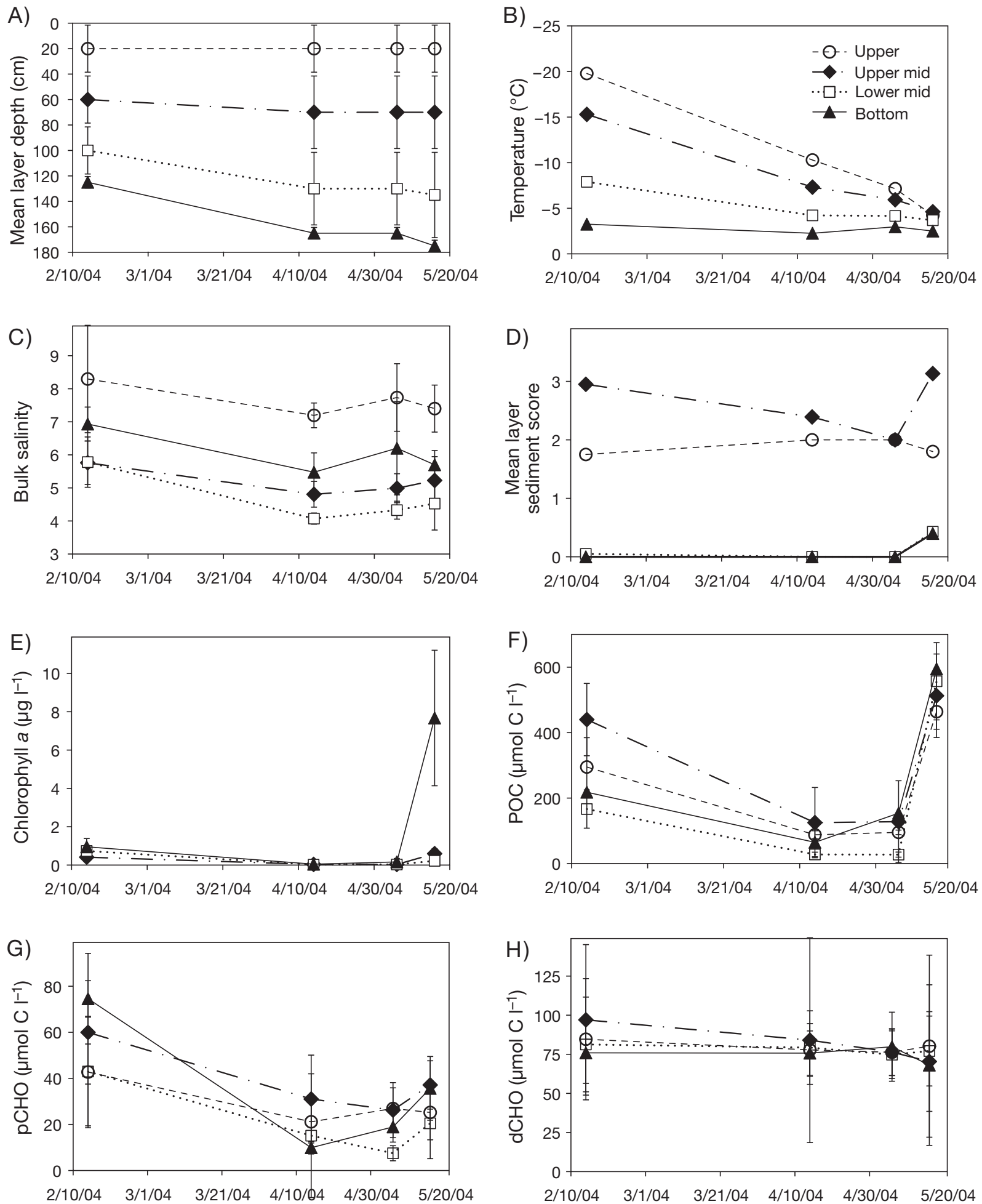

Fig. 4. Temporal development of physical, chemical, and biological variables in sediment-containing sea ice sampled during spring 2004. Each panel (A to H) shows a single variable through time for 4 layers defined by depth within the ice: upper, upper middle, lower middle, and bottom layers (see 'Organic pools in sediment-free ice' and Fig. 2 for more details). (A) Mean depth for each layer (bars show the depth range of ice sections pooled for each layer), (B) temperature (note reversed $y$-axis), (C) bulk salinity, (D) mean sediment score, (E) bulk chl $a_{1}(\mathrm{~F})$ bulk POC, (G) bulk pCHO, and (H) bulk dCHO are shown. For bulk salinity, sediment score, chl $a, \mathrm{pCHO}$, and $\mathrm{dCHO}$, samples from 5 replicate ice cores were analyzed on each date. For the bottom layer (bottom $10 \mathrm{~cm}$ ) the symbol is the mean $( \pm 1 \mathrm{SD})$ of the bottom layer across the 5 cores. For each of the 3 upper layers, the symbol is the grand mean ( \pm the pooled SD) of all segments within a depth layer from all cores collected on each date. POC was only analyzed in 1 of the 5 cores from each date. For the bottom layer, each symbol represents the value from the bottom $10 \mathrm{~cm}$ of that ice core. For the upper layers, each symbol is the mean ( $\pm 1 \mathrm{SD})$ of all segments within a layer from the single core. Dates: month/day/year 
Table 3. Correlation matrix for the primary variables sampled in sediment-containing ice during winter and spring 2004. Correlations were based on the mean values for each variable at a given depth from 5 ice cores (except particulate organic carbon [POC], which was measured in single ice cores on each date). Different depths and times were considered independent, resulting in 65 data pairs for each correlation. For each data pair, the Pearson correlation coefficient (r) and, in parentheses, the corresponding p-value are given. Bold: correlations with $\mathrm{p}<0.05$. pCHO: particulate carbohydrates; dCHO: dissolved carbohydrates; sediment score: relative sediment content

\begin{tabular}{|c|c|c|c|c|c|c|}
\hline & Bulk salinity & Chl a & POC & $\mathrm{pCHO}$ & $\mathrm{dCHO}$ & Sediment score \\
\hline Temperature & $0.55(<0.0001)$ & $0.13(0.31)$ & $<0.01(0.99)$ & $0.47(0.0001)$ & $0.29(0.02)$ & $0.35(0.003)$ \\
\hline Bulk salinity & - & $<0.01(0.99)$ & $0.09(0.46)$ & $0.27(0.03)$ & $0.10(0.43)$ & $0.25(0.04)$ \\
\hline Chl a & & - & $0.31(0.01)$ & $0.22(0.08)$ & $0.09(0.47)$ & $0.06(0.65)$ \\
\hline POC & & & - & $0.39(0.0012)$ & $0.01(0.95)$ & $0.34(0.005)$ \\
\hline $\mathrm{pCHO}$ & & & & - & $0.17(0.17)$ & $0.55(<0.0001)$ \\
\hline $\mathrm{dCHO}$ & & & & & & $0.14(0.25)$ \\
\hline
\end{tabular}

(Fig. 4H). Mean dCHO in the water ranged from

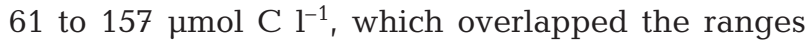
found in the different ice layers and was somewhat lower than mean values in the previous year.

The Pearson correlation coefficients and corresponding $\mathrm{p}$-values for pairs of variables measured on the 2004 samples of sediment-containing ice are given in Table 3. As in sediment-free ice, chl a was correlated with $\mathrm{POC}$, but not with $\mathrm{pCHO}$ or $\mathrm{dCHO}$. POC and pCHO were significantly correlated, as in the previous year, but, unlike the earlier results, $\mathrm{POC}$ and dCHO were not correlated. In addition, both POC and pCHO (but not dCHO) were correlated with the sediment score.

\section{Comparing sediment-free and sediment-containing ice}

Differences in the development of and relationships between organic pools in the sedimentcontaining and sediment-free ice sampled were plausibly related to the presence or absence of a sediment layer, rather than spatial or temporal variability. In sediment-free ice, autochthonous organic matter production was indicated by the increase in $\mathrm{POC}$ and $\mathrm{pCHO}$ through time, especially in the bottom layer. Quantitative separation of $\mathrm{POC}$ and $\mathrm{pCHO}$ pools between the upper and bottom ice layers did not develop in sediment-containing ice, probably because high light attenuation by the sediment layer inhibited the growth of ice algae near the ice bottom (Gradinger et al. 2009, Lee et al. 2010), while the sediment inclusions provided a high organic matter background in the upper layers. The relationship between chl $a$ and POC was weaker than in sediment-free ice, and the strongest relationships for $\mathrm{POC}$ and $\mathrm{pCHO}$ were with the sediment score (and with each other). These correlations suggest that the sediments were a source of particulate organic material to the ice. The only dissolved organic pool measured was $\mathrm{dCHO}$, which, unlike in sediment-free ice, did not correlate with any of the particulate pools measured and changed little through time in all ice layers.

Despite autochthonous organic matter production in the sediment-free ice, it is worth noting that the concentrations of organic matter in sedimentcontaining ice were comparable, and often higher than in the sediment-free ice. While this observation highlights the potential contribution of sedimentderived organic matter to sea-ice carbon budgets, it is worth noting that the organic matter concentrations measured throughout our study were relatively low compared to some previous studies of land-fast Arctic sea ice. For example, peak POC values of 2300

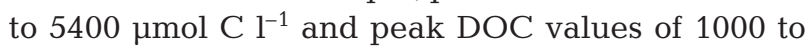
$5800 \mu \mathrm{mol} \mathrm{C} \mathrm{l}^{-1}$ were described by Smith et al. (1997), Junge et al. (2004), and Riedel et al. (2008). As already mentioned, high values such as these may be related to high algal biomass in the bottom ice layer.

One observation that was common across years was the generally higher concentration of dissolved organic pools relative to the corresponding particulate pools at a given depth horizon in the ice (i.e. DOC $>$ POC, dCHO > pCHO). A notable exception to this generality was in the bottom $10 \mathrm{~cm}$ of sedimentfree ice in April, May, and June of 2003, i.e. during and after the peak of the algal bloom. A similar scenario was found by Riedel et al. (2008), whereby DOC in the ice bottom (lowest $4 \mathrm{~cm}$ ) exceeded POC before the ice algal bloom, but the relative pool sizes then reversed in later samples. Thus, the background condition for first-year, land-fast Arctic sea ice, found in young ice and maintained in the upper ice layers, may be for dissolved organic pools to exceed particu- 
late organic pools. When conditions allow, autochthonous particulate organic matter can increase and eventually dominate organic pools near the ice bottom.

Another similarity between sediment-containing and sediment-free ice was the predominant contribution of the upper ice layers to integrated POC and DOC pools. For seasonal sea ice, such as that we sampled, the organic contents of the entire ice column will be exported to the water column as the ice melts each year. While the contribution of the upper ice layers to integrated organic pools described here may not be universally representative, it is worth highlighting that, for seasonal Arctic sea ice, the annual organic flux out of the ice during the melt can be dominated by the organic pools from the upper layers of the ice. This point may increase in relevance as the relative areal cover of seasonal sea ice increases in the Arctic (e.g. Comiso 2002, Kwok \& Cunningham 2010). Given the high organic matter concentrations found in sediment-containing ice, sediment-containing ice would be expected to supply a high POC and DOC flux upon melting, although the pigment flux would be low.

\section{Decline of the ice algal bloom}

In the sediment-free ice sampled in 2002 and 2003, there was a significant decrease in the chl a in the bottom layer of ice between the last 2 sampling dates $\left(t_{8}=7.05, \mathrm{p}=0.0001\right)$. Mean $( \pm \mathrm{SD})$ ice thickness decreased slightly (from $128.8 \pm 1.1$ to $124.6 \pm 1.9 \mathrm{~cm}$ ) over the same period, though not significantly $\left(t_{8}=\right.$ $1.9, \mathrm{p}=0.09$ ). Meanwhile, $\mathrm{POC}$ and $\mathrm{pCHO}$ increased (significant increase for $\mathrm{pCHO}\left[t_{8}=3.6, \mathrm{p}=0.007\right]$ ), DOC fell slightly (by $15 \%$ ), and dCHO increased, though not significantly $\left(t_{8}=0.03, \mathrm{p}=0.98\right)$. Thus, loss of algal biomass was not accompanied by loss of other organic pools.

The time between samples bracketing the decline of ice algae was fairly long in 2003. Therefore, sampling of sediment-free ice was repeated in May 2006 to focus on this period in more detail. While development of the bloom was not followed during the 2006 sampling, we were able to follow the decline of the bloom in the bottom layer with greater temporal resolution. Bulk variables in the ice sampled in 2006 were comparable in magnitude to the sediment-free ice samples from 2003. For example, the peak values of chl $a$, POC, DOC, and pCHO in the bottom ice sampled in 2006 were within a factor of 2 of corresponding peak values in the bottom layer of ice sampled in 2003 (Table 4). Between 12 and 21 May 2006 the chl a concentration increased by a mean of $50 \%$. However, from 21 to 26 May, chl a decreased significantly $\left(t_{8}=5.5, \mathrm{p}=0.006\right)$. There were small, but significant, decreases in ice thickness and bulk salinity over the same period ( $t$-tests, $\mathrm{df}=8$; ice thickness: $\mathrm{p}=0.009$; salinity; $\mathrm{p}=0.006$ ). Other variables were only measured on 12 and 26 May. POC and pCHO increased significantly ( $t$-tests, df $=8$; POC: $\mathrm{p}=0.003$; pCHO: $\mathrm{p}=0.01$ ); however, DOC and dCHO did not change significantly ( $t$-tests, df $=8$; DOC: $p=0.30$; dCHO: $p=0.90$ ). Thus, in both seasons of observations of sediment-free ice (2002 to 2003 and 2006), there was a significant decline in chl a between the last 2 sampling dates. However, large POC and DOC pools remained in the ice bottom layer after the decline of the bloom. Similarly, in both years, the carbohydrate fractions did not decrease.

\section{Observation of melting ice cores}

In 2006, the bottom segments of several sedimentfree ice cores were gradually melted in seawater $\left(2^{\circ} \mathrm{C}\right)$ to simulate rapid bottom ablation. Alcian Blue staining revealed a network of EPS strands (stained blue, see Feature Article [FA] photograph on p. 1) that largely remained attached to the ice, even as the supporting structure of ice crystals melted away. The FA photograph was taken after $8 \mathrm{~h}$ of melting: uneven melting during this period produced a

Table 4. Summary of variables measured in ice cores collected in spring 2006 . Each value is the mean $( \pm 1 \mathrm{SD})$ from the bottom $10 \mathrm{~cm}$ of 5 paired ice cores collected along a $10 \mathrm{~m}$ transect on each date. Some variables were only measured on 12 and 26 May 2006

\begin{tabular}{|c|c|c|c|c|c|c|c|c|}
\hline Date & $\begin{array}{l}\text { Snow depth } \\
\text { (cm) }\end{array}$ & $\begin{array}{l}\text { Ice thickness } \\
(\mathrm{cm})\end{array}$ & $\begin{array}{c}\text { Bulk } \\
\text { salinity }\end{array}$ & $\begin{array}{c}\mathrm{Chl} \mathrm{a} \\
\left(\mu \mathrm{g} \mathrm{l}^{-1}\right)\end{array}$ & $\begin{array}{c}\text { POC } \\
\left(\mu \mathrm{mol} \mathrm{C} l^{-1}\right)\end{array}$ & 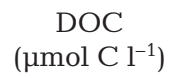 & $\begin{array}{c}\text { pCHO } \\
\left(\mu \mathrm{mol} \mathrm{C} 1^{-1}\right)\end{array}$ & 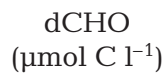 \\
\hline 12 May & $22.3 \pm 7.6$ & $128 \pm 1.1$ & $5.0 \pm 0.1$ & $26.5 \pm 3.6$ & $105 \pm 27$ & $373 \pm 46$ & $50 \pm 17$ & $368 \pm 46$ \\
\hline 21 May & $14.9 \pm 11.7$ & $132 \pm 2.2$ & $5.0 \pm 0.1$ & $38.5 \pm 10.7$ & - & - & - & - \\
\hline 26 May & $9.0 \pm 7.2$ & $126 \pm 1.3$ & $4.6 \pm 0.2$ & $10.2 \pm 4.5$ & $212 \pm 33$ & $408 \pm 60$ & $80 \pm 12$ & $363 \pm 36$ \\
\hline
\end{tabular}


curved ice-water interface. As indicated by labelled arrows in the FA photograph, clumps of algae were visible hanging from the ice on the EPS strands. Moving the ice segment caused many of the algal clumps to detach from the ice and sink to the bottom of the container, but the EPS strands themselves remained attached to the ice. This description, and the photograph shown, are both highly reminiscent of observations and images made by under-ice divers in coastal Antarctica (McConville et al. 1985, see their Figs. 2 \& 3 in particular). In addition, the observation of an EPS network remaining in the ice after algal cells have sloughed off is consistent with field observations showing retention of EPS (quantified using Alcian Blue staining) in Arctic sea ice after the loss of ice algae (Riedel et al. 2006, 2008, see following subsection).

\section{Differential retention of sea-ice organic pools}

Our observations demonstrate that the increase in particulate organic matter in the lower layers of sediment-free sea ice was associated with an increase in ice algae. However, substantial dissolved and particulate organic matter pools were found in the ice before the seasonal ice algal bloom, and additional organic pools were found in depth strata that were unlikely to be directly affected by algal activity. In other ice samples, organic matter was also associated with sediment inclusions. Connecting the various organic pools in sea ice to eventual organic fluxes out of the ice will require further research, but our observations highlight the potential for differential retention during ice melt of some organic pools relative to others.

When the majority of ice algae were lost from sediment-free sea ice in late spring, large carbohydraterich particulate and dissolved organic matter pools remained in the ice bottom layer, as well as in the upper layers. Loss of ice algae was therefore temporally discontinuous from the other organic matter pools. Simulation of bottom ablation indicated that a network of EPS strands, probably produced by ice algae, had a high affinity for ice and remained entangled in the ice after the algae had fallen off. Retention of such an EPS network in field samples could partly explain the carbohydrate-rich POC pools that remained in the ice after loss of the algae. These observations are consistent with observations of EPS retention in the bottom layer of Arctic sea ice following the loss of ice algae (Riedel et al. 2006, 2008). Retention of EPS by sea ice is also suggested by the undersampling of EPS from sackhole brines (Underwood et al. 2010). Riedel et al. (2006) postulated that EPS retained in sea ice could provide a secondary pulse of organic matter export from the ice following the initial release of algal biomass. Similarly, the dissolved and particulate organic matter observed in the present study, which remained at all depths in the ice after the loss of algae, would also eventually be exported to the water column as seasonal ice melt progressed. While the initial loss of algae can occur over a few days (as we observed in 2006), secondary fluxes of the remaining organic matter may be more gradual, and they may also differ from the initial flux of algae with respect to properties such as sinking rates and nutritional quality for consumers. Thus, differential retention of organic matter in sea ice suggests that organic fluxes from the ice change qualitatively through time and could be categorized (at least conceptually) into different sequential phases. The fate in the water column of these different organic fluxes after loss from the ice remains an open research question.

Acknowledgements. The authors thank the excellent support staff of BASC for their assistance with sampling and for keeping them safe. Comments from Prof. R. Gradinger and 4 anonymous reviewers were helpful in improving the manuscript. This research was supported by grants from the National Science Foundation, ARC-0221055 and ARC0454955 to C.K., and ARC-0454726 to A.R.J. K.M.M. was supported through a Gaylord Donnelley Environmental Fellowship by the Yale Institute for Biospheric Studies/ Department of Geology and by the Australian Government Cooperative Research Programme through the Antarctic Climate and Ecosystems Cooperative Research Centre. This is contribution no. 7489 of Lamont Doherty Earth Observatory.

\section{LITERATURE CITED}

Ambrose WG, Clough LM, Tilney PR, Beer L (2001) Role of echinoderms in benthic remineralization in the Chukchi Sea. Mar Biol 139:937-949

Arrigo KR (2003) Primary production in sea ice. In: Thomas DN, Dieckmann GS (eds) Sea ice. An introduction to its physics, chemistry, biology, and geology. Blackwell, Oxford, p 143-183

Arrigo KR, Thomas DN (2004) Large-scale importance of sea ice biology in the Southern Ocean. Antarct Sci 16: $471-486$

> Avanzino RJ, Kennedy VC (1993) Long-term frozen storage of stream water samples for dissolved orthophosphate, nitrate plus nitrite, and ammonia analysis. Water Resour Res 29:3357-3362

Bluhm BA, Gradinger RR, Schnack-Schiel SB (2010) Sea ice meio- and macrofauna. In: Thomas D, Dieckmann G (eds) Sea ice. Wiley-Blackwell, Oxford, p 357-394

Bradstreet MSW, Cross WE (1982) Trophic relationships at high Arctic ice edges. Arctic 35:1-12 
Comiso J (2002) A rapidly declining perennial sea ice cover in the Arctic. Geophys Res Lett 29:1956-1959

> Cota GF, Legendre L, Gosselin M, Ingram RG (1991) Ecology of bottom ice algae. I. environmental controls and variability. J Mar Syst 2:257-277

Decho AW (1990) Microbial exopolymer secretions in ocean environments: their role(s) in food webs and marine processes. Oceanogr Mar Biol Annu Rev 28:73-153

Dubois M, Gilles KA, Hamilton JK, Reber PA, Smith F (1956) Colorimetric method for the determination of sugars and related substances. Anal Chem 28:350-356

Eddie B, Juhl A, Krembs C, Baysinger C, Neuer S (2010) Effect of environmental variables on eukaryotic microbial community structure of land-fast Arctic sea ice. Environ Microbiol 12:797-809

Eicken H (2003) From the microscopic, to the macroscopic, to the regional scale: growth, microstructure and properties of sea ice. In: Thomas DN, Dieckmann GS (eds) Sea ice. An introduction to its physics, chemistry, biology, and geology. Blackwell, Oxford, p 22-81

Fortier M, Fortier L, Michel C, Legendre L (2002) Climatic and biological forcing of the vertical flux of biogenic particles under seasonal Arctic sea ice. Mar Ecol Prog Ser 225:1-16

Giannelli V, Thomas DN, Kennedy HA, Dieckmann GS, Kattner G, Haas C (2001) The behavior of dissolved organic matter during sea ice formation. Ann Glaciol 33: 317-321

Gosselin M, Levasseur M, Wheeler PA, Horner RA, Booth BC (1997) New measurements of phytoplankton and ice algal production in the Arctic Ocean. Deep-Sea Res II 44: 1623-1644

> Gradinger RR, Spindler M, Hentschel D (1991) Development of Arctic sea-ice organisms under graded snow cover. Polar Res 10:295-307

> Gradinger RR, Kaufmann MR, Bluhm BA (2009) Pivotal role of sea ice sediments in the seasonal development of nearshore Arctic fast ice biota. Mar Ecol Prog Ser 394:49-63

Haecky P, Jonsson S, Andersson A (1998) Influence of sea ice on the composition of the spring phytoplankton bloom in the northern Baltic Sea. Polar Biol 20:1-8

Herborg LM, Thomas DN, Kennedy H, Haas C, Dieckmann GS (2001) Dissolved carbohydrates in Antarctic sea ice. Antarct Sci 13:119-125

Horner R, Ackley SF, Dieckmann GS, Gulliksen B and others (1992) Ecology of sea ice biota. 1. Habitat, terminology, and methodology. Polar Biol 12:417-427

> Hsiao SIC (1992) Dynamics of ice algae and phytoplankton in Frobisher Bay. Polar Biol 12:645-651

> Juhl AR, Krembs C (2010) Effects of snow removal and algal photoacclimation on growth and export of ice algae. Polar Biol 33:1057-1065

> Junge K, Eicken H, Deming J (2004) Bacterial activity at -2 to $-20^{\circ} \mathrm{C}$ in Arctic wintertime sea ice. Appl Environ Microbiol 70:550-557

Krembs C, Deming JW (2007) The role of exopolymers in microbial adaptation to sea ice. In: Margesin R, Schinner F, Marx JC, Gerday C (eds) Psychrophiles: from biodiversity to biotechnology. Springer, Heidelberg, p 247-264

- Krembs C, Engel A (2001) Abundance and variability of microorganisms and transparent exopolymer particles across the ice-water interface of melting first-year sea ice in the Laptev Sea (Arctic). Mar Biol 138:173-185

Krembs C, Eicken H, Junge K, Deming JW (2002) High concentrations of exopolymeric substances in Arctic winter sea ice: implications for the polar ocean carbon cycle and cryoprotection of diatoms. Deep-Sea Res I 49: 2163-2181

Krembs C, Eicken H, Deming JW (2011) Exopolymer alteration of physical properties of sea ice and implications for ice habitability and biogeochemistry in a warmer Arctic. Proc Natl Acad Sci USA 108:3653-3658

> Kwok R, Cunningham GF (2010) Contribution of melt in the Beaufort Sea to the decline in Arctic multiyear ice coverage: 1993-2009. Geophys Res Lett 37:L20501 doi: 10.1029/2010GL044678

> Lee S, Jin M, Whitledge T (2010) Comparison of bottom seaice algal characteristics from coastal and offshore regions in the Arctic Ocean. Polar Biol 33:1331-1337

Legendre L, Ackley SF, Dieckmann GS, Gulliksen B and others (1992) Ecology of sea ice biota. 2. Global significance. Polar Biol 12:429-444

> Lizotte MP (2001) The contributions of sea ice algae to Antarctic marine primary production. Am Zool 41:57-73

Lizotte MP (2003) The microbiology of sea ice. In: Thomas DN, Dieckmann GS (eds) Sea ice. An introduction to its physics, chemistry, biology, and geology. Blackwell, Oxford, p 184-210

McConville MJ, Mitchell C, Wetherbee R (1985) Patterns of carbon assimilation in a microalgal community from annual sea ice, East Antarctica. Polar Biol 4:135-141

> McMahon KW, Ambrose WG, Johnson BJ, Sun MY, Lopez GR, Clough LM, Carroll ML (2006) Benthic community response to ice algae and phytoplankton in Ny Aalesund, Svalbard. Mar Ecol Prog Ser 310:1-14

Meiners K, Gradinger R, Fehling J, Civitarese G, Spindler M (2003) Vertical distribution of exopolymer particles in sea ice of the Fram Strait (Arctic) during autumn. Mar Ecol Prog Ser 248:1-13

> Meiners K, Brinkmeyer R, Granskog MA, Lindfors A (2004) Abundance, size distribution and bacterial colonization of exopolymer particles in Antarctic sea ice (Bellingshausen Sea). Aquat Microb Ecol 35:283-296

- Meiners K, Krembs C, Gradinger R (2008) Exopolymer particles: microbial hotspots of enhanced bacterial activity in Arctic fast ice (Chukchi Sea). Aquat Microb Ecol 52: 195-207

> Michel C, Legendre L, Therriault JC, Demers S, Vandevelde $\mathrm{T}$ (1993) Springtime coupling between ice algal and phytoplankton assemblages in southeastern Hudson Bay, Canadian Arctic. Polar Biol 13:441-449

- Michel C, Legendre L, Taguchi S (1997) Coexistence of microalgal sedimentation and water column recycling in a seasonally ice-covered ecosystem (Saroma-ko Lagoon, Sea of Okhotsk, Japan). J Mar Syst 11:133-148

> Mundy CJ, Barber DG, Michel C (2005) Variability of snow and ice thermal, physical and optical properties pertinent to sea ice algae biomass during spring. J Mar Syst 58:107-120

> Passow U (2002) Production of transparent exopolymer particles (TEP) by phyto- and bacterioplankton. Mar Ecol Prog Ser 236:1-12

> Passow U, Alldredge AL (1995) A dye-binding assay for the spectrophotometric measurement of transparent exopolymer particles (TEP). Limnol Oceanogr 40:1326-1335

> Reimnitz E, Marincovich L, Mccormick M, Briggs WM (1992) Suspension freezing of bottom sediment and biota in the Northwest Passage and implications for Arctic Ocean sedimentation. Can J Earth Sci 29:693-703

Renaud PE, Riedel A, Michel C, Morata N, Gosselin M, Juul- 
Pederson T, Chiuchiolo A (2007) Seasonal variation in benthic community oxygen demand: a response to an ice algal bloom in the Beaufort Sea, Canadian Arctic? J Mar Syst $67: 1-12$

Riedel A, Michel C, Gosselin M (2006) Seasonal study of sea-ice exopolymeric substances on the Mackenzie shelf: implications for transport of sea-ice bacteria and algae. Aquat Microb Ecol 45:195-206

Riedel A, Michel C, Gosselin M, Leblanc B (2007) Enrichment of nutrients, exopolymeric substances and microorganisms in newly formed sea ice on the Mackenzie shelf. Mar Ecol Prog Ser 342:55-67

Riedel A, Michel C, Gosselin M, Leblanc B (2008) Winterspring dynamics in sea ice carbon cycling in the coastal Arctic Ocean. J Mar Syst 74:918-932

Runge JA, Therriault JC, Legendre L, Ingram RG, Demers S (1991) Coupling between ice microalgal productivity and the pelagic, metazoan food web in southeastern Hudson Bay-a synthesis of results. Polar Res 10:325-338

Smith REH, Anning J, Clement P, Cota G (1988) Abundance and production of ice algae in Resolute Passage, Canadian Arctic. Mar Ecol Prog Ser 48:251-263

Smith REH, Gosselin M, Kudoh S, Robineau B, Taguchi S (1997) DOC and its relationship to algae in bottom ice communities. J Mar Syst 11:71-80

Stedmon CA, Thomas DN, Granskog M, Kaartokallio H, Papadimitriou S, Kuosa H (2007) Characteristics of dissolved organic matter in Baltic coastal sea ice: allochtho-

Editorial responsibility: Andrew Brierley, St. Andrews, UK; Matthias Seaman, Oldendorf/Luhe, Germany nous or autochthonous origins? Environ Sci Technol 41: 7273-7279

Thomas DN, Papadimitriou S (2003) Biogeochemistry of sea ice. In: Thomas DN, Dieckmann GS (eds) Sea ice. An introduction to its physics, chemistry, biology, and geology. Blackwell, Oxford, p 267-302

> Thomas DN, Kattner G, Engbrodt R, Giannelli V, Kennedy H, Haas C, Dieckmann GS (2001) Dissolved organic matter in Antarctic sea ice. Ann Glaciol 33:297-303

$>$ Tremblay C, Runge JA, Legendre L (1989) Grazing and sedimentation of ice algae during and immediately after a bloom at the ice-water interface. Mar Ecol Prog Ser 56: 291-300

Underwood GJC, Fietz S, Papadimitriou S, Thomas DN, Dieckmann GS (2010) Distribution and composition of dissolved extracellular polymeric substances (EPS) in Antarctic sea ice. Mar Ecol Prog Ser 404:1-19

UNESCO (1994) Protocols for the Joint Global Ocean Flux Study (JGOFS) core measurements. Manual and Guides, IOC, Paris

Verdugo P, Alldredge AL, Azam F, Kirchman DL, Passow U, Santschi PH (2004) The oceanic gel phase: a bridge in the DOM-POM continuum. Mar Chem 92:67-85

Wingender J, Neu TR, Flemming HC (1999) What are bacterial extracellular polymeric substances? In: Wingender J, Neu TR, Flemming HC (eds) Microbial extracellular polymeric substances. Characterization, structure and function. Springer, Berlin, p 1-20

Submitted: March 12, 2009; Accepted: June 30, 2011 Proofs received from author(s): August 15, 2011 